\title{
Road Map Towards Zero Water Milk-processing Plants \\ - Experiences from a Danish Public-Private Partnership
}

\author{
Palle Lindgaard-Jørgensen (Corresponding author) \\ DHI \\ Agern Allé 5, DK-2970 Hoersholm, Denmark \\ Tel: 45-4516-9200Ｅ-mail: plj@ dhigroup.com
}

Gert Holm Kristensen \& Martin Andersen

IN-Water ApS

J.P. Larsens Vej 68, DK-8220 Brabrand, Denmark

Tel: 45-6065-9470Ｅ-mail: maa@in-water.dk

Received: January 10, 2018 Accepted: January 26, 2018 Published: March 27, 2018

doi:10.5296/emsd.v7i2.12893 URL: https://doi.org/10.5296/emsd.v7i2.12893

\begin{abstract}
A three-year public-private partnership project in Denmark, with participation of food and environment authorities, branch organizations, technology providers, universities and applied research organizations, mapped the water use and installed water-saving technologies in four cheese-producing dairy plants and a milk-processing plant with mixed dairy products.

The objective of the work was: (i) to document that reuse of water in the participating milk processing plants did not compromise product safety, and (ii) to develop methodologies to select best technologies as well as monitoring and control procedures for milk processing.

Different mapping approaches were tested: water meters with online data transmission, detailed mapping of all water uses and a mapping that focused on the water uses which were expected to have the largest water-saving potential.

Based on the results of the water use mapping, water efficiency scenarios for the plants were developed, and solutions were selected according to their water-saving potential, applicability in the dairy sector, cost-efficiency and sustainability.

Selected technologies were tested in full-scale in a number of dairy processes, including reuse
\end{abstract}


and increased efficiency in utilities and cleaning operations, optimization and renewal of milk-processing operations, reuse of permeate from RO filtration for concentration of whey and reuse of dairy waste water in utility functions. The investment costs for the installation of technologies were recorded as well as the actual water savings, energy savings and savings in labour time. The savings were substantial and could pay back the investment costs, often in less than a year - with the longest payback time being five years.

A branch code was developed by the partnership providing guidance for water reuse in the dairy industry, including HACCP, monitoring and control procedures for reuse of water in CIP and other dairy processes and for storage and reuse of water from whey and milk concentration.

A dairy, which applies the guidance and regulations in the branch code and adopts a combination of the technologies tested by the partnership, may save up to $60 \%$ of its present water use. The partnership also led to a vision for a zero water dairy, which would require; however, that new technologies and regulations would be developed and tested.

Keywords: Milk-processing plants, Water reuse, Water and energy savings, Best practice technologies, Regulation of water reuse, Food safety

\section{Introduction}

Water is an essential resource for food and drink production. With worldwide water scarcity being a serious concern, the industry is increasingly aiming at addressing the impact of its water consumption and discharge of waste water and considering ways in which it can optimize water use in the future whilst ensuring the safety and wholesomeness of its products (Tortajada, C., 2016).

The Danish dairy sector comprises 38 dairy enterprises with 53 milk-processing plants, of which 65\% produce hard or soft cheese (Danish Agriculture and Food Council, 2015). The sector uses 7 million $\mathrm{m}^{3}$ of groundwater $(1 \%$ of the total Danish water use or $10 \%$ of the Danish food sector water use). The groundwater is supplied by public water utilities (40\%) and company-owned wells $(60 \%)$. Waste water from the milk processing plants is treated in public or in company-owned waste water treatment plants to comply with local emission regulations. The amount of milk processed has increased during recent years, while the number of milk-processing plants has decreased resulting in an increased pressure on local water resources and capacities of local waste water treatment plants. The Danish milk powder and milk ingredient industry has spearheaded increased water efficiency in the dairy sector. Cheese producers have been more reluctant to reuse water partly due to tradition; however, also based on lack of good business cases and full-scale documentation of safe solutions and safeguards.

The overall objective of the public-private partnership was to document that reduction of the water use per unit of milk processed and waste water discharged could be reduced without compromising milk product safety (Lindgaard-Jørgensen. P. et al., 2017).

The key research questions for a safe reuse in the milk-processing plants were: (i) Can water 
in the milk (cow water) replace the use of fresh groundwater and for which processes? (ii) Can water used in the cleaning process be reused in the countercurrent process? (iii) Can water use be reduced in cleaning processes and other processes through online monitoring of water and water quality? (iv) Can water streams discharged to waste water treatment plants be reused as utility water after treatment?

Denmark has positive experience with implementing research in public-private partnerships where relevant partners, including regulators, research institutions, technology providers and end-users of solutions, work for a common goal and share knowledge and research results. In the present partnership, a key objective was to develop safe solutions, which would convince the food safety authorities that reused water could safely replace the fresh groundwater and at the same time convince the milk-processing plants that the solutions would not introduce any risks to the product safety and that investments and running costs for reuse solutions would have short payback times.

\section{Materials and Methods}

\subsection{Water Use Mapping}

A detailed water balance or model, which identifies the volume of water used in each area of the milk-processing plant, was undertaken. Three different mapping methodologies were used: (i) Manual data reading of water meters combined with local measurement of water use of specific processes, such as seal water use in pumps. The aim of this monitoring was to get as close as possible to a $100 \%$ accounting for the water use in the plants. (ii) Installation of online water meters at strategic locations in the milk-processing plants and development of a data collection system to automatically process water meter data. The aim was to be able to identify key water volumes and uses, how they developed over time and to identify leakages and track the effect of installation of new water-saving technologies. (iii) Overall identification of water uses with a potential for reuse - focusing on the CIP process and reuse of water contained in the milk. The aim was to identify large water streams that could result in a major reduction of the use of groundwater, provided the quality of the water would be sufficient to comply with the requirements in a specific process. The water use data from each of the processes/water meters in the milk-processing plant were added up resulting in an overall milk-processing water balance, which could be compared to the water intake meters of the plant, and more detailed water balances for each of the milk-processing plant production areas and unit operations. The water balance also accounted for the input (in milk) and output (in products) of the "water" contained in the milk processed.

\subsection{Water-saving and Reuse Scenarios}

A systematic approach was used to identify the potential for reducing the use of groundwater. The aim of the approach was to identify easily implementable and low-cost savings first and then to progress gradually to more advanced solutions, if further water use reductions were needed. The approach (called 6Rs) was based on a prioritized analysis of the potential to: Reduce, Renew, Reuse, Recycle, Reclaim and Return water, and the "water-fit-for purpose" methodology was used to assess if a water stream could be reused or recycled. In all analyses, 
the following criteria were used to assess the saving and reuse scenarios: Food safety (undertaken by the milk-processing plants' own Hazard Analysis Critical Control Point (HACCP) teams), pay-back of investment (calculated as ratio between investment costs and savings in costs for water supply, waste water discharge, energy and labour costs), level of innovation and eco-efficiency of the solution, including both life cycle costs and life cycle environmental impact assessments.

\subsection{Full-scale Testing and Documentation of Water Savings and Reuse}

Eleven safe scenarios for testing and documentation were selected for full-scale implementation. The installation of the technologies was undertaken by staff of the participating plants, supported by technology developers/suppliers. The participating plants supervised the operation and performance of the technologies and the product quality and safety. The research institutions of the partnership developed a documentation programme with a list of parameters to be collected by the plants (water supply, waste water generation, energy, chemicals and labour time used for operation). In a few cases, water samples were taken and analysed with chemical (COD, urea and nutrients) and microbial analysis (bacterial count using MPN technique), colony morphology and growth potential in milk water streams of selected strains of Listeria, Salmonella and Kleibsella.

The tested and documented scenarios focused on: reduction of water use through smart integration and dissemination of water meter data, renewed equipment for reduced water use in CIP through better control of the outlet from the cleaning process, reuse of rinse water and recycling of whey water after membrane filtration, recycling of technical water for Pasteur cooling and washing of cheese forms, reclaiming water from membrane filtered milk/cow water for cooling water and, in general, replacement of fresh groundwater. Ultraviolet technology was used for all water streams that could potentially contain microorganisms.

\subsection{Partnership Process and Development of Innovative Regulation}

At the start of the partnership project, the partners agreed that a significant reduction of water use in milk-processing plants would require a close cooperation between regulators of food safety, water resources and environmental quality, technology developers and research/consultancy organizations. This was needed in order to develop methodologies for water metering, develop solution scenarios, design solutions and to document effects of solutions. The active involvement of milk-processing plants that were willing to implement solutions in full scale and involve their HAACP and production teams was also of key importance. The milk-processing plants did not consider water use as a "competitive factor" and therefore freely shared information on water use and process flow and allowed all partners - including regulatory authorities and other milk-processing plants - to visit their plants. This led to a trustful relationship between all partners and an open discussion and testing of which new regulatory framework could satisfy the requirement of both the regulators and the milk-processing plants. The new regulation of water reuse was developed as an element of a new branch code providing guidance to the milk-processing plants on $\mathrm{HACCP}$ and operational plans, monitoring and control procedures. 


\section{Macrothink}

\section{Results}

\subsection{Water Use in the Milk-processing Plants}

The water-to-milk ratios in the milk-processing plants are shown in Table 1. Many milk-processing plants use this ratio to track their overall consumption. The ratios are within the European range of 0.2-11 1/kg reported by Daufin et al. (2001) and the Australian range of 0.07-2.9 1/kg reported by UNEP (2004) and above the range of 0.5-0.78 reported for cheese production in UK by Milani, F.X., Nutter, D. \& Thoma, G. (2011) (Rad and Lewis, 2014).

The ratios for waste water to milk are within the European range of $0.2-11 \mathrm{l} / \mathrm{kg}$ reported by Daufin et al. (2001). The waste water ratios for the milk-processing plants are influenced by the amount of whey sent to other milk-processing plants producing powder and ingredients.

The COD in the waste water from the milk-processing plants ranges from 1800 to $4000 \mathrm{mg} / \mathrm{l}$. The COD is mainly a result of loss of product. The total loss of product per year from the plants is estimated to $139-839$ tons of milk protein, if all COD is calculated as milk protein (Rad and Lewis, 2014).

Table 1. Water-to-milk ratios $(1 / \mathrm{kg})$ in milk-processing plants

\begin{tabular}{|l|l|l|l|}
\hline Main product & $\begin{array}{l}\text { Annual amount of } \\
\text { milk processed in ton }\end{array}$ & $\begin{array}{l}\text { Water-to-milk } \\
\text { ratio }(\mathrm{l} / \mathrm{kg})\end{array}$ & $\begin{array}{l}\text { Waste water-to-milk } \\
\text { ratio }(\mathrm{l} / \mathrm{kg})\end{array}$ \\
\hline $\begin{array}{l}\text { Cheese, market milk, } \\
\text { milk products }\end{array}$ & 115000 & 1.29 & 1.35 \\
\hline Yellow hard cheese 1 & 60000 & 1.36 & 0.83 \\
\hline Yellow hard cheese 2 & 550000 & 1.36 & 1.30 \\
\hline White Cheese & 55000 & 1.84 & 1.54 \\
\hline Mozzarella cheese & 750000 & 0.68 & 0.79 \\
\hline Powdered products & 510000 & 0.88 & - \\
\hline
\end{tabular}

Water is used in the milk-processing plants for processing and cleaning, for the operation of utilities such as steam production and cooling water and for other uses such as canteens and personal hygiene for staff. Figure 1 shows an example of a breakdown of water use in an organic milk-processing plant that produces milk, milk products and cheese. This milk-processing plant producing many different products has frequent cleaning of their production equipment to push out any remaining products before a new production is started. The cleaning therefore also takes up a substantial part of the overall water use. The breakdown of the main water uses (Table 2) shows that there are significant differences in the water use, depending among other things on the milk products produced, the amount of milk processed, the age of the production equipment, the management's focus on water saving and the extent to which water is already being reused. 


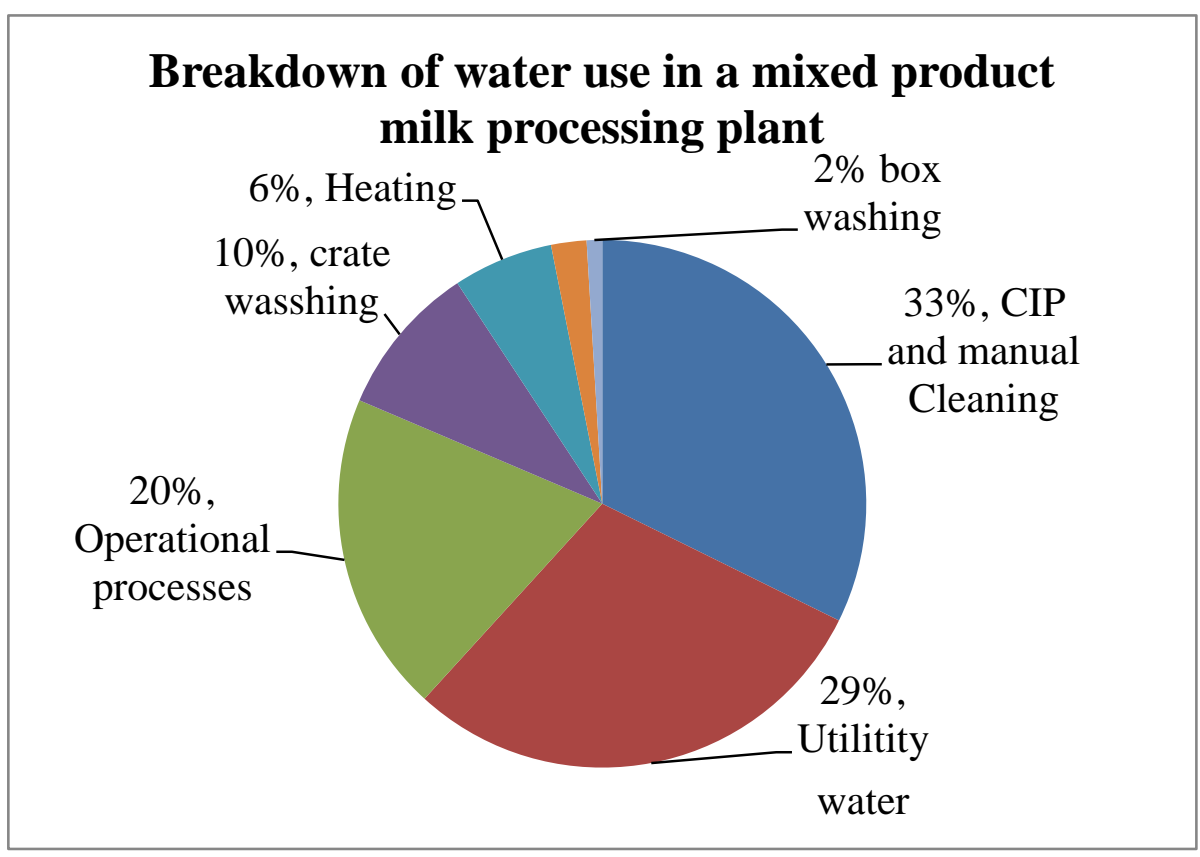

Figure1. Breakdown of water use in a mixed product milk-processing plant (monthly averages)

Table 2. Main water uses (in $\%$ of total water use) in milk-processing plants

\begin{tabular}{|l|l|l|l|l|}
\hline Main product & $\begin{array}{l}\text { Cleaning } \\
(\% \text { of total })\end{array}$ & $\begin{array}{l}\text { Operational processes } \\
(\% \text { of total })\end{array}$ & $\begin{array}{l}\text { Seal } \\
\text { water }\end{array}$ & $\begin{array}{l}\text { Utility water } \\
(\% \text { of total })\end{array}$ \\
\hline $\begin{array}{l}\text { Cheese, market milk, } \\
\text { milk products }\end{array}$ & 33 & 14 & 6 & 29 \\
\hline Yellow hard cheese 1 & 13 & 30 & 6 & 26 \\
\hline White cheese & 53 & 15 & 15 & 17 \\
\hline Mozzarella cheese & 58 & 17 & 10 & 9 \\
\hline
\end{tabular}

Based on the water uses shown in Table 2, the milk-processing plants decided which types of uses needed the most attention in the technology scenarios described in the following.

\subsection{Technology Scenarios - Development and Assessment}

The mapping results lead to a number of scenarios using the 6Rs and "water-fit-for-purpose" approach. Prior to the partnership project, the milk-processing plants had already implemented significant water-saving projects, and the focus of the partnership was therefore on renewed and more water-efficient technologies, on optimizing the cleaning processes and on recycling of cow water to replace the use of fresh drinking water.

Cheese producing milk-processing plants have significant amounts of whey water (milk contains $88 \%$ of water), which potentially can be reused and replace the use of fresh groundwater, provided that the whey water can be treated to a level where there is no risk related to the product. Analysis of whey water after treatment in reverse osmosis plants showed among other things low concentrations of urea and microorganisms. Scenarios for reusing whey water should therefore comprise reverse osmosis and UV treatment 
technologies and, in case of further needs for reduction, also an additional step of polishing using another membrane filtration step.

Saving water in a specific milk process may be achieved in a number of ways, with widely different combinations of technologies, investment costs, level of innovation and feasibility of the use of new technologies and needs for control and monitoring of product safety and environmental impacts.

Only scenarios that did not introduce any risks to the production were selected for further testing, and a simple scoring system was developed to score investment costs, payback time and level of innovation of the technology applied.

Technology scenarios developed for each of the milk-processing plants comprised:

- Reduction of water use through better monitoring of water use and process control

- Renewal of equipment with limited or no use of seal water and cooling systems with no water use

- Automatic control of outlet from CIP to assess when a system is sufficiently clean

- Reuse of rinse water in the CIP system using a countercurrent system

- Recycling of whey water (reverse osmosis permeate from treated whey, separated in the cheese production) for various purposes

- Use of reclaimed process streams/waste water treated in a membrane bioreactor system for technical purposes

- Return of clean process streams directly to streams

\subsection{Full-scale Testing of Water-saving and Reuse Technologies}

Full-scale testing of water-saving and reuse technologies resulted in significant water and cost savings (see Table 3). 


\section{Ml Macrothink}

Environmental Management and Sustainable Development

ISSN 2164-7682

2018, Vol. 7, No. 2

Table 3. Documented savings resulting from installation of technologies in milk-processing plants

\begin{tabular}{|c|c|c|c|c|}
\hline $\begin{array}{l}\text { Milk-processing } \\
\text { plant }\end{array}$ & $\begin{array}{l}\text { Technology tested } \\
\text { in full scale }\end{array}$ & $\begin{array}{l}\text { Investment in } \\
\text { technology in } \\
1000 \text { Euro }\end{array}$ & $\begin{array}{l}\text { Value of } \\
\text { savings in } 1000 \\
\text { uro/year }\end{array}$ & $\begin{array}{l}\text { Documented } \\
\text { savings in } \% \text { of } \\
\text { total water use }\end{array}$ \\
\hline $\begin{array}{l}\text { Mixed dairy } \\
\text { products }\end{array}$ & $\begin{array}{l}\text { Smart metering and data } \\
\text { integration }\end{array}$ & 33 & 25 & 5.0 \\
\hline $\begin{array}{l}\text { Mixed dairy } \\
\text { products }\end{array}$ & $\begin{array}{l}\text { Constant flow valves for seal } \\
\text { water }\end{array}$ & 5.4 & 4 & 1.2 \\
\hline Yellow cheese & $\begin{array}{l}\text { Renewal and upgrading of the } \\
\text { CIP process }\end{array}$ & 173 & 29 & 6.9 \\
\hline Yellow cheese & $\begin{array}{l}\text { RO treated whey water reused } \\
\text { for cooling }\end{array}$ & 100 & 90 & 4.7 \\
\hline Yellow cheese & $\begin{array}{l}\text { RO treated whey water reused } \\
\text { for last CIP rinse }\end{array}$ & 69 & 86 & 4.3 \\
\hline Yellow cheese & $\begin{array}{l}\text { RO treated whey water reused } \\
\text { for final CIP rinse, washing of } \\
\text { forms and cooling at Pasteur }\end{array}$ & 56 & 206 & 10.2 \\
\hline Mozarella & $\begin{array}{l}\text { Reuse of MBR treated in } \\
\text { cooling condensator }\end{array}$ & 253 & 40 & 9.0 \\
\hline Yellow cheese & Reuse of seal water for pumps & 77 & 26 & 6.4 \\
\hline White cheese & $\begin{array}{l}\text { Conductivity of outlet from last } \\
\text { rinse }\end{array}$ & 21 & 15 & 4.5 \\
\hline $\begin{array}{l}\text { Mixed dairy } \\
\text { products }\end{array}$ & $\begin{array}{l}\text { Recycling of middle and last } \\
\text { rinse in CIP }\end{array}$ & 140 & 43 & 10.0 \\
\hline $\begin{array}{l}\text { Mixed dairy } \\
\text { products }\end{array}$ & $\begin{array}{l}\text { RO treated cow water used as } \\
\text { process water }\end{array}$ & 126 & 75 & 16.0 \\
\hline
\end{tabular}

The total water saving for the technologies tested (Table 3) amounts to $200000-250000 \mathrm{~m}^{3}$ per year corresponding to an average of $15 \%$ of the total water use of $1600000 \mathrm{~m}^{3}$ for the milk-processing plants participating in the partnership. The savings of each milk-processing plant vary from 4 to $50 \%$ depending on the investments in technology undertaken by the plant. The large savings are in milk-processing plants that optimized the CIP process through recycling of rinse water and better monitoring of the quality of the outflow from the last rinse in CIP and through the reuse of cow water treated in reverse osmosis membrane systems. The value of the savings on the water bill is 0.65 million Euros/year. When savings in energy, chemicals and labour cost are also included, the annual savings amount to 0.8 million Euro. In view of the total investment costs of around 1.1 million Euro, this is assessed to be a short average payback time for investments in water saving.

\subsection{Innovative Regulation of Water Reuse}

The full-scale testing and the observations showing that products produced during the test periods were safe resulted in an improved basis for regulating water that originates from 
drinking water and "water" which was originally an element of milk and therefore considered as food.

For water (originally drinking water), the following has to be adhered to by the milk-processing plants:

- Water which is not of drinking water quality has to be kept separated from water of drinking water quality, and pipes must be marked accordingly

- Water which is used in milk processing or as an ingredient, and which is of the same standard as drinking water, can be used without prior approval

- Water which is used in milk processing or as an ingredient, and which is of another standard as drinking water, requires approval by the food authorities

For whey water, the following food regulation has to be observed:

- Whey water which is in contact with food products cannot be accepted for use, if there is evidence that it is polluted with parasites, pathogenic microorganisms or hazardous chemicals to an extent which makes the food product unsuitable for consumption

- Whey water has to be kept under suitable conditions, preventing degradation and contamination

- Whey water must not be kept at temperatures which can lead to health risks

- Use of whey water must take place following procedures based on the HACCP principles

The partnership drafted a branch code (Danish EPA, 2017) comprising concrete scenarios, which replace the requirement for individual milk-processing plant applications and approvals of water-saving and reuse projects. Further, the partnership agreed that reuse of last and middle rinse water in the CIP process would not introduce any food safety risk if well monitored and that use of UV treatment of RO treated cow water prior to other uses would further reduce any food safety risks.

\section{Discussion}

A detailed mapping of water use is generally agreed as a precondition for a comprehensive reduction of water use (Perry, C., 2011; Mavrov, V. \& Belieres, E., 2000; Rad and Lewis, 2014). In the present project, the methodologies applied were sufficiently detailed to lead to the identification of scenarios using the 6Rs and "water-fit-for-purpose" approach. However, each methodology applied had its pros and cons.

The very detailed analysis, which accounted for $95 \%$ of the water used, was very labour-intensive and required substantial commitment from the management of the milk-processing plants. However, the analysis was successful in identifying seal water as a significant water use, raising the awareness at management level. 


\section{Macrothink}

The smart metering and information system on water use had a high investment cost but had its benefits in providing an ongoing monitoring of water use, in its ability to support awareness raising in the plant and in tracking leakages and other failures during operation of the plant. The approach focusing on the highest volumes for water-savings was the least labour-intensive mapping method. While there was a potential that this method could have missed some water uses, it actually led to the identification of significant water-saving scenarios.

Knowledge about water quality of a water stream is important, when a stream is to be reused or recycled in the plant (Fryer, P. J., Christian, G. K. \& Liu, W., 2006; Casani, S., Rouhany, M. \& Knøchel, S., 2005; Rad and Lewis, 2014). In the present project, the water quality of the water streams to be reused or recycled was not tested, except for cow water. Instead, each scenario was discussed with the milk-processing HACCP team and, if needed, additional barriers to improve the food safety level were introduced (like e.g. UV treatment or polishing). This approach was considered feasible by the partnership and a good approach for the day-to-day optimization of water use in the milk-processing plants.

The technologies applied (Table 3) had all been tested in pilot scale or some even in full scale (Bosworth, M., Hummelsmose, B., Christiansen, K., 2000; Olivier, P., Rodriguez, R. \& Udaquiola, S., 2008; Vourch, M., Balannec, B., Chaufer, B. \& Dorange, G., 2008; Özbay, A. \& Demirer, G.N., 2007).

The partnership project added to the literature by documenting in full scale a number of technological solutions, in particular: (i) the product safety, feasibility and cost-efficiency of using membrane technologies combined with UV light for whey water, and (ii) measurement of conductivity in the outlet from CIP as a feasible technology for reducing water use in CIP. The project further documented that recycling of rinse water in CIP is also feasible and that process streams containing waste water can be treated and reused for technical water.

Combining a number of these technologies will bring milk-processing plants closer to cost-efficient zero water plants as illustrated in Figure 2. Scenarios 1-4 are the results of the implementation of technologies installed in the mixed dairy product plant presented in Table 3 , with a return of investment of less than one year. Adding scenario 5 and 6 will result in a $60 \%$ saving potential. This requires additional treatment of the waste water from the plant as well as use of the cow water for technical purposes and additional treatment, both scenarios having a longer return of investment than one year. 


\section{Macrothink}

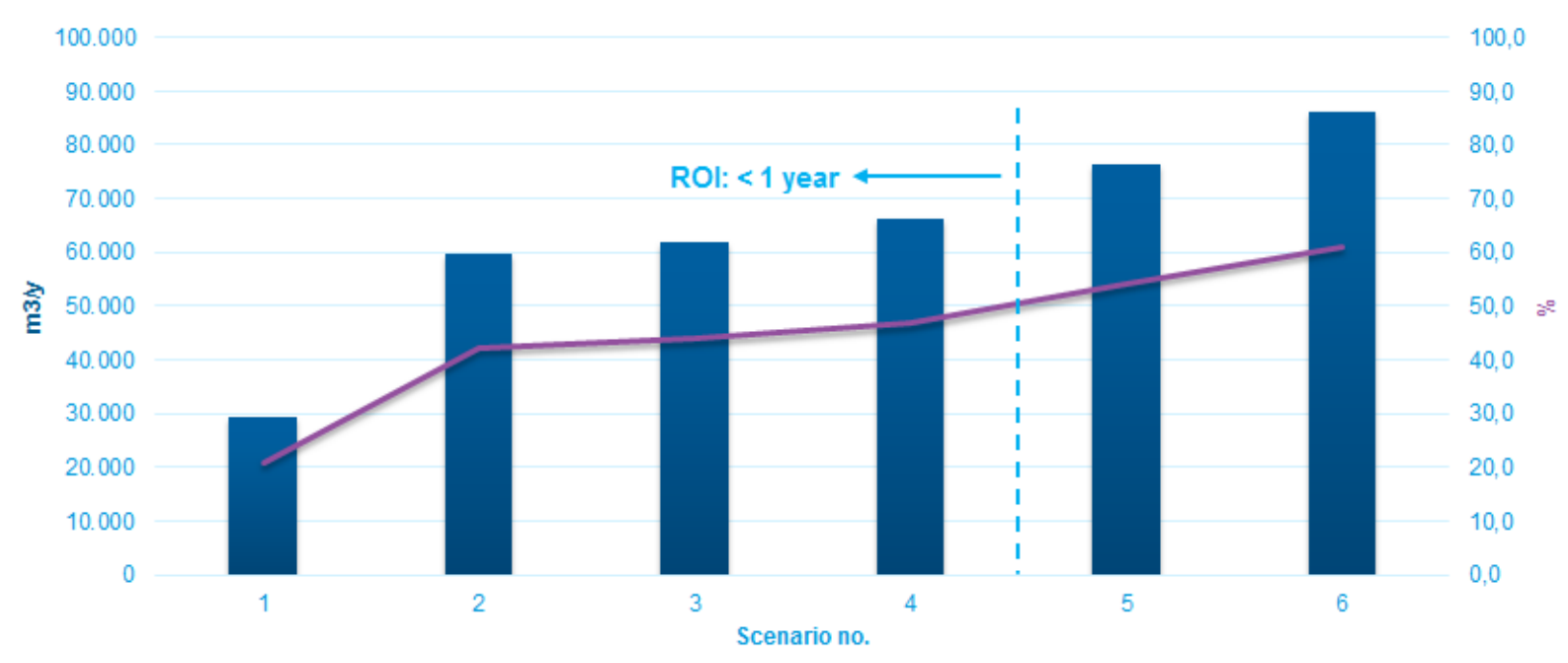

Figure 2. Expected savings in the mixed dairy product plant (accumulated $\mathrm{m}^{3} /$ year and accumulated \%)

If the saving should be even higher and approaching $100 \%$ to achieve a zero water milk-processing plant, the waste water would have to be treated to a level where it can replace the use of drinking water in processes which are in contact with the milk products. This option was not tested, as the risk to products was considered too high by the partnership.

The documentation of technologies and the innovative regulation developed are, however, expected to substantially increase the water saving in the milk-processing sector in Denmark. If all milk-processing plants producing cheese or mixed products applied the technologies developed by the partnership, the savings would amount to 1.5-2.2 million m3/year, corresponding to an estimated reduction of $20-30 \%$. The cheese producing milk-processing plants were having the largest saving potential.

\section{Conclusion}

Mapping of water use and development of water-saving and reuse scenarios using the "water-fit-for-purpose" approach are very useful approaches to increase the water use efficiency in the food industry. The study documented that a number of water-saving technologies could be installed in milk-processing plants without any food safety risks to the product. Savings on the water supply and in particular on the waste water treatment cost as well as on the energy, chemicals and labour costs were substantial and the payback time for the technology investment could be from less than one year to a few years.

Scenarios that combined a number of technologies for reuse of cow water and recycling in cleaning systems were most efficient in reducing the water use. It is realistic for the milk processing plants to achieve a reduction of up to 50-60\% in water use, and with a higher degree of reuse of waste water some of the milk-processing plants can get close to reaching a zero water target.

The study further showed that a partnership model can increase trust between industries and regulators and assist in developing innovative regulation which removes barriers for 
increased water efficiency in the food sector.

\section{Acknowledgement}

This partnership project was supported by a grant from the Danish EPA (Grant number NST-404-00182) and co-financed by the partners of the partnership. The authors wish to thank the following contributors to the partnership project: Martin Rygaard, Technical University of Denmark, Claus Heggum and Henrik Borg Kristensen, Danish Agriculture and Food Council, Søren Aabo, University of Copenhagen, Esben Rahbek Gjerdrum Pedersen, Copenhagen Business School and Finn Skov Nielsen, Krüger.

\section{References}

Tortajada, C. (Ed), (2016). World Water Council: Increasing Resilience to Climate Variability and Change. Springer.

Danish Agriculture and Food Council (2015). Dairy Statistics.

Lindgaard-Jørgensen, P. et al. (2017). Partnership on water efficient dairies (in Danish). Report to Danish EPA.

Prasad, P. et al. (2004). Eco-efficiency for the Dairy Processing Industry. UNEP Working Group for Cleaner Production in the Food Industry.

Casani, S., Rouhany, M., \& Knøchel, S. (2005). A discussion paper on challenges and limitations to water reuse and hygiene in the food industry. Water Research, 6(39), 1134-1146. https://doi.org/10.1016/j.watres.2004.12.015

Fryer, P. J., Christian, G. K., \& Liu, W. (2006). How hygiene happens: physics and chemistry of cleaning. International Journal of Dairy Technology, 2(59), 1134-1146.

https://doi.org/10.1111/j.1471-0307.2006.00249.x

Mavrov, V., \& Belieres, E. (2000). Reduction of water consumption and wastewater quantities in the food industry by water recycling using membrane processes. Desalination, 131, 75-86. https://doi.org/10.1016/S0011-9164(00)90008-0

Olivier, P., Rodriguez, R., \& Udaquiola, S. (2008). Water use optimization in batch process industries. Part 1: design of the water network. Journal of Cleaner Production, 16, 1275-1286. https://doi.org/10.1016/j.jclepro.2007.06.012

Rad, S. J., \& Lewis, M. J. (2014). Water utilisation. Energy utilisation and waste water management in the dairy industry: A review. International Journal of Dairy Technology, 67, 1-10. https://doi.org/10.1111/1471-0307.12096

Milani, F. X., Nutter, D., \& Thoma, G. (2011). Environmental impacts of dairy processing and products: A review. Journal of Dairy Science, 9(94), 4242-4254.

Bosworth, M., Hummelsmose, B., \& Christiansen, K. (2000). Cleaner Production Assessment in Dairy Processing. COWI Consulting Engineers and Planners AS, Denmark, pp. 17-21.

Vourch, M., Balannec, B., Chaufer, B., \& Dorange, G. (2008). Treatment of dairy industry 


\section{Macrothink \\ Environmental Management and Sustainable Development \\ ISSN 2164-7682 \\ 2018, Vol. 7, No. 2}

wastewater by reverse osmosis for water reuse. Desalination, 219, 190-202.

https://doi.org/10.1016/j.desal.2007.05.013

Özbay, A., \& Demirer, G. N. (2007). Cleaner production opportunity assessment for a milk processing facility. Journal of Environmental Management, 84(4), 484-493.

https://doi.org/10.1016/j.jenvman.2006.06.021

Perry, C. (2011). Accounting for water use: Terminology and implications for saving water and increasing production. Agricultural Water Management, 98, 1840-1846.

https://doi.org/10.1016/j.agwat.2010.10.002

\section{Copyright Disclaimer}

Copyright for this article is retained by the author(s), with first publication rights granted to the journal.

This is an open-access article distributed under the terms and conditions of the Creative Commons Attribution license (http://creativecommons.org/licenses/by/3.0/). 